\title{
Reflection on rules in science: an invisible-hand perspective
}

\author{
Thomas C. Leonard
}

\begin{abstract}
Can successful science accommodate a realistic view of scientific motivation? The Received View in theory of science has a theory of scientific success but no theory of scientific motivation. Critical Science Studies has a theory of scientific motivation but denies any prospect for (epistemologically meaningful) scientific success. Neither can answer the question because both regard the question as immaterial. Arguing from the premise that an adequate theory of science needs both a theory of scientific motivation, and a theory of scientific success, I make a case for seeing science as a kind of invisible-hand process. After distinguishing different and often confused conceptions of invisible-hand processes, I focus on scientific rules, treated as emergent responses to various coordinationfailures in the production and distribution of reliable knowledge. Scientific rules, and the means for their enforcement, constitute the invisible-hand mechanism, so that scientific rules (sometimes) induce interested scientific actors with worldly goals to make epistemically good choices.
\end{abstract}

Keywords: theory of science, scientific motivation, economics of science, invisible hand, reliable knowledge, scientific institutions

\section{INTRODUCTION}

Science is a social enterprise, and its practitioners are flesh and blood people motivated by more than truth and the social good. That so few contemporary scholars of science would disagree is a measure of how much the image of science has been transformed in the 40 years since Kuhn's Structure of Scientific Revolutions. Why then, as so ably documented by Wade Hands (2001), the disarray and controversy in modern theory of science? The answer is that any adequate theory of science requires not only a theory of scientific motivation, but also a view of good scientific outcomes, and how they come to be produced. Even with agreement on the virtues of a more realistic conception of scientific motivation, (and on idea that social science can aid in the understanding of science), there remain deep disagreements on the consequences, for scientific knowledge in particular, of adopting a more realistic conception of scientific motivation.

The traditional image of science - also known as the Received View (Suppe 1977) - clearly believed that science could be successful. Its project, after all, 
was to reduce that success to a set of logical, even algorithmic rules for grinding out truth claims, sometimes known as Scientific Method. But the Received View failed to offer any theory of scientific motivation, and thus, whatever the merits of its normative case for Method, had no way of knowing whether real scientists had the right incentives to follow the Scientific Method. What I call Critical Science Studies (CSS) suffers from the obverse problem. ${ }^{1}$ It offers a theory of scientific motivation, portraying scientists as (at least partly) self-interested and as having worldly goals similar to economic agents. At the same time, however, CSS abandons as impossible the entire normative project of the theory of science. CSS scholars defend, and often assume 'cognitive egalitarianism', 'the thesis that all beliefs are epistemically or evidentially equal in terms of their support' (Laudan 1984: 29-31). The Received View has a theory of scientific success but no theory of scientific motivation. CSS has a theory of scientific motivation but denies any prospect for (epistemologically meaningful) scientific success. Thus neither can answer the important question - can successful science accommodate a realistic view of scientific motivation? - because both regard the question as immaterial.

This paper's premise is that the question deserves an answer, that is, that an adequate theory of science must offer both a theory of scientific motivation, and a theory of scientific success. I will not argue for this premise except as follows. We need a theory of scientific success, because the natural sciences, while fallible and imperfect, and not immune to politics, bias, fashion and fad, have nonetheless been the most successful of human cognitive endeavours (Haack 1998: 130). Unless science's success is denied or can be regarded as an accident of happenstance, or as inherently inexplicable, it's worth investigating how it is accomplished. ${ }^{2}$ The idea is that science studies must not only describe the practices of scientists, but analyse how scientific practices succeed or fail in accomplishing cognitive goals.

We also need a theory of scientific motivation, even if it is the theory that scientists - professional skeptics - will blindly heed the rules laid down for them by lawgiving philosophers of science. If one regards scientists as sometimes having interests opposed to what the rules dictate, then it matters whether the rules are incentive compatible. The history of science suggests that the rules are frequently not observed. There may be something wrong with the rules (Feyerabend's 1975 conclusion, for example), or, alternatively, the rules may be fine, but there are incentive problems, or both. Without a theory of scientific motivation, there is no basis for distinguishing among these rival explanations, and, in addition, there is no prospect for identifying scientifically good rules that interested scientists will opt to follow.

The present task is to ask: under what circumstances can a real community of fallible, 'epistemically sullied' (Kitcher 1993: 384) inquirers achieve the good outcomes traditionally thought to require ideal inquirers (Haack 1998: 98). Invisible-hand explanations suggest themselves naturally to an economist - they are deeply rooted in the disciplinary ethos. This paper offers 
a case for seeing science as a kind of invisible-hand process. But, if it is to have any explanatory force, the term 'invisible hand' must be more than a label for a black-box process. I emphasize scientific rules, which I treat as emergent responses to various market failures in the production and distribution of scientific ideas. Scientific rules, and the means for their enforcement, constitute the invisible-hand mechanism, by which I mean: scientific rules induce (partly) interested scientific actors with worldly goals to make choices that (sometimes) lead to epistemically good scientific outcomes. ${ }^{3}$ Scientific rules are discussed in Section 5, as three prefatory tasks precede it.

First, any attempt to reconcile successful science with a realistic view of scientific motivation, must consider the current impasse in science studies, which means understanding why both Received-View and CSS theories of science regard the project of reconciliation as moot. This task takes up Section 2. Second, any reconciliation will likely require a more pragmatic conception of scientific knowledge than the traditional conception of justified true belief. I suggest, in Section 3, the alternative of reliable knowledge, a concept developed by Alvin Goldman (1986) and others. Third, any attempt to use in science studies the name 'invisible hand', which is often a term of derision outside of economics, must distinguish Adam Smith's sense of the term unintended if planned-looking beneficial consequences - from cognate meanings, such as laissez-faire and Pareto optimality. I distinguish the different interpretations of 'invisible hand' in Section 4.

\section{THE RECEIVED VIEW: THE TRADITIONAL IMAGE OF SCIENCE}

Once upon a time, theorists of science, who were then overwhelmingly philosophers with epistemological concerns, offered an image of how science should proceed. (The rest of this paragraph is taken, only lightly paraphrased, from Kuhn 1992: 4-5). Nature was its starting point, as was the claim that phenomena arrive to inquirers in the forms of observations that are facts accessible to and indubitable for all normally equipped human observers. Facts were the objective basis of the laws, theories and explanations for which they provided the foundation. And while laws, theories and explanations, which interpret given facts, may be arrived at variously, the process by which scientists choose among rival interpretations - theory choice - was said to be governed by the data. That is, the facts can be said to adjudicate among rival interpretations of them. The process of adjudication constitutes the scientific method, a logical and, in some versions algorithmic, means by which scientists arrive at true generalizations about and explanations for natural phenomena - and if not true, at least approximations to true, and if not certain approximations, then at least highly probable ones. In sum, Kuhn says, the central pillars of the Received View image of science, pillars on which the epistemic authority of science was said to rest, are two: 'first, that facts 
are prior to and independent of the beliefs for which they are said to supply the evidence, and, second, that what emerges from the practice of science are truths, probable truths, or approximations to truth about a mind- and culture-independent external world' (Kuhn 1992: 18).

As noted, traditional theories of science simply did not attend to the question of scientific motivation. Received View theory is normative and prescriptive, reflecting its genesis in philosophy. Here are the rules - a logic of discovery - that, correctly applied, will produce scientific knowledge. Should scientists opt not to observe them, so much the worse for science. Put this elliptically, the foregoing account risks caricature, but it suffices for our purposes.

\subsection{The Revisionist critique of the Received View: scientific method and motive}

History has been unkind to the Received View. Beginning roughly mid-20th century, a distinguished group of scholars - Karl Popper, Stephen Toulmin, Norwood Hanson, Willard Quine, Imre Lakatos, Paul Feyerabend, and Thomas Kuhn among them - assembled a compelling critique. I select and emphasize two key arguments from what is a wide-ranging critique: (1) that the Received View image of scientific method is flawed-i.e., that it is incorrect as an account of what scientists should do, and (2) that the Received View image of science is itself unscientific, in the sense that it did not systematically attend to (nor believe that it had to attend to) the question of whether the empirical practice of science actually comported with its theory of science.

Revisionist skepticism on scientific method begins with the nature and function of facts in the Received View. Regarding the nature of facts, Quine (1953) argued that, since experience is not prior to belief, facts are not prior to theoretical interpretation. Facts are, rather, unavoidably contaminated by the theories devised to explain them. Scientists, in practice, have no choice but to look for data under the street lamps of theory. The problem is particularly acute with experimental apparati, the design and operation of which may themselves depend upon theory, sometimes upon the very theory being tested. If facts are theory-laden, then, contra the traditional image, they cannot serve as a neutral court in which rival theories are tried (Kuhn 1992: 4-5).

The Quine-Duhem hypothesis attacks the Received View image of facts on another, nearby front. Even if scientists reach agreement on what the facts are, there is the problem of determining exactly what the facts say regarding the theory they are meant to confront. When evidence contradicts theory, what has gone wrong? Is it the theory, or the evidence? And, if it is the theory, which component - the main hypothesis (e.g., consumers maximize utility), an auxiliary hypotheses (e.g., rates of time preference are invariant) or a ceteris paribus condition (e.g., nominal income is constant along a Marshallian demand curve), or other (e.g., only equilibrium states are of 
theoretical interest)? In Quine's elegant phrasing: 'our statements about the external world face the tribunal of sense experience not individually, but only as a corporate body' (1953: 41). Thus, implies the Duhem-Quine argument, when tests disconfirm, 'the choice of where exactly to point the accusing finger of refutation, is ours, not nature's ...' (Hollis 1994: 80).

Theory underdetermination extends the Duhem-Quine indeterminancy the worry about which elements of a given theory are disconfirmed - to the problem of choice among rival theories. In particular, when there are incompatible theories that are empirically equivalent, a given body of evidence will be equally confirming or disconfirming of all theoretical rivals. ${ }^{4}$ If, per these revisionist objections to the Received View, facts can not unambiguously choose among theoretical rivals, there is broad scope for scientific disagreement. But since there is nonetheless scientific consensus even when the facts do not speak unambiguously, it must be the case that theory choice has a non-evidentiary aspect. Once facts can no longer carry the entire burden of theory choice, the door is open to explaining scientific belief by reference to non-evidentiary criteria - beauty, parsimony, political or ideological biases, class membership, research agenda, the potential for generating fame or fortune, and so on.

The second element of the revisionist critique I emphasize is the idea that theories of science should themselves be scientific - in particular that the empirical strategies of science should be used in theory of science as well. ${ }^{5}$ This view in theory of science is typically referred to as 'naturalistic' and its proponents as naturalizers ${ }^{6}$ (Callebaut 1993).

Revisionist scholars, including those most influential in economic methodology, were hardly blind to incentive problems. Popper and Lakatos, for example, generally regarded scientists as self-interested. Popper worried that opportunistic scientists would resort to ad hoc 'immunizing stratagems' when the data proved inconvenient for their pet theories, and he proposed a welter of rules aimed to forestall various kinds of hypothesis-rescuing dodges (Popper 1972: 15-16). So perhaps Lakatos is unfair when he criticizes Popper's rule of falsification on incentive grounds:

Popper's [demarcation] criterion ignores the remarkable tenacity of scientific theories. Scientists have thick skins. They do not abandon a theory merely because facts contradict it. They normally invent some rescue hypothesis to explain what they then call a mere anomaly or, if they cannot explain the anomaly, they ignore it ...

Regardless, there is the question of how the meta-scientific theorist should regard theoretical evidence that scientists have perverse incentives, or empirical evidence from history of science that scientists do not, for example, ruthlessly falsify their own theories. Economic methodologists have long noted the routine failure of economists to apply Popper's strict method of 
refutation (Archibald 1967). A naturalizing theorist of science might argue that the failure of scientists to ruthlessly falsify should be seen as evidence that Popper's falsification criterion is itself refuted (or at least unscientific), by its own lights. But Popper is no naturalizer. He does not regard his meta-scientific claims as rules justified by an examination of the history of science, and he does not regard his meta-scientific claims as testable by evidence from scientific practice $^{7}$ (1959: 52).

The idea that theory of science cannot and should not itself be scientific changes with Kuhn, himself trained in physics. Kuhn believed what scientists have actually done is relevant to any theory of what they should do. The traditional image of science prescribed rigorous testing of theory by facts, but, in legislating from the armchair, ignoring the history of science, was unscientific when self-applied. Kuhn in contrast, conceived of theory of science in scientific terms. Kuhn's naturalism was not new, but Kuhn gets the credit for reviving naturalism in post-war philosophy of science. ${ }^{8}$ 'Kuhn liberated us', says William Wimsatt, 'not only to do history of science, but also science. History of science is after all just science looked at after it has happened' (Callebaut 1993: 24).

Kuhn's historical turn was thus theoretically motivated. Kuhn regarded scientific practice as rather different than what prevailing philosophy of science then prescribed. Faced with this anomaly - scientists don't do what philosophers of science say they should do - Kuhn turned to history not to debunk the scientific enterprise, but to improve the theory of science. 'What we mostly thought we were doing', summarizes Kuhn in a retrospective, 'was building a philosophy of science on observations of scientific life, the historical record providing our data' (1992: 4).

Before the naturalistic turn in theory of science, the few social scientists who studied scientific rules still deferred to the Received-View bifurcation between the practice of science and the product of science, scientific knowledge. Pioneers like Robert Merton (1973) mostly hewed to the traditional philosophical distinction between study of science (loosely, what philosophers called the context of discovery) and the study of knowledge (loosely, what philosophers called the context of justification). Merton argued that social factors could influence, for example, the selection of research problems (1973 [1957]: 554). But Merton was traditional in not admitting social factors into the determination of scientific knowledge, arguing:

The criteria of validity of claims to scientific knowledge are not matters of national taste and culture. Sooner or later, competing claims to validity are settled by the universalistic facts of nature which are consonant with one and not with another theory. ${ }^{9}$

(ibid.)

This mid-century deference to the authority of philosophy in matters of scientific knowledge is almost poignant in retrospect, and it did not last long. 


\subsection{Critical Science Studies' view of science}

Critical Science Studies (CSS) takes a variant of Kuhnian naturalism, and weds it to a radical skepticism that derives from an especially strong reading of the revisionist arguments on theory ladenness and theory underdetermination. Science, says CSS, essentially inverting the traditional formulation, knows nothing.

Though most revisionists argued that the facts alone could not determine scientific belief, they were also clear that, as Kuhn put it, 'observation and experience can and must drastically restrict the range of admissible scientific belief, else there would be no science' (1996 [1962]: 4). If the revisionists diminished the role of facts in the determination of scientific belief, CSS scholars, running through a breach opened by Quine, deny facts any role whatsoever in theory choices made by scientists. ${ }^{10} \mathrm{CSS}$ claims, in effect, that underdetermination amounts to undetermination of theory by data.

For CSS scholars, empirical evidence never influences theory choice. Scientists may (falsely) invoke the influence of data for rhetorical purposes, but, says Harry Collins, 'the natural world has a small or non-existent role in the construction of scientific knowledge' (1981: 3). '[W]e can never use . . . Nature', argues Bruno Latour, 'to explain how and why a [scientific] controversy has been settled' (1987: 99). Some even elevate the view that evidence never affects scientific belief into a methodological injunction: 'explanations [in science studies] should be developed within the assumption that the real world does not affect what the scientist believes about it' (Collins and Yearly 1992: 372). And, if evidence is immaterial, then appeals to data and reason, ubiquitous in science, must be regarded as mere posturing. 'Science legitimates itself by linking its discoveries to power', says Stanley Aronowitz, 'a connection which determines not merely influences what is to count as reliable knowledge' (1988: 204, cited in Haack 1998: 102).

The CSS sense of the term 'social' is perhaps now clearer. It is meant as an antonym for 'natural' in explaining the causes of scientific belief. It refers in particular to the social subset of non-evidential determinants of scientific belief - social class, political ideology, gender and so on. It is this subset of non-evidential determinants that CSS scholars emphasize, while others invoke non-evidential determinants not obviously social, such as theoretical parsimony, or internal consistency, or congruency with other theories regarded as true.

\subsection{Do social influences necessarily undermine knowledge?}

The revisionist worry, shared by Kuhn and familiar to social scientists, was that the presence of non-evidential criteria might prove inimical to science. Non-evidential determinants of scientific belief clearly threaten the objectivity that the Received View said was provided by impartial adjudication by facts. 
The CSS view of knowledge dispenses with that worry, by the route of denying that science could ever produce anything worth protecting in the first place. If science is entirely social, then objectivity is not just unattainable, it is incoherent. CSS scholars thus regard the normative project of determining whether scientific practices (social and other) promote or undermine scientific knowledge as obviated. When knowledge is demoted to belief, description is all theory of science can attempt. ${ }^{11}$ CSS thus begs the vital question of whether (and to what extent) social influences undermine or promote scientific knowledge.

For a brief period, some important CSS scholars adopted a debunking strategy with a less totalizing critique. During this era, CSS emphasized how social factors worked to undermine knowledge - a critique from social science rather than from epistemology. Instead of arguing that knowledge is in principle unattainable, they argued that interested scientists with noncognitive goals would not produce it (Latour and Woolgar 1986). The argument implied that the selfless truth seeking of the idealized inquirer was a necessary condition for the production of scientific knowledge. This line of inquiry was influential for a time, and it invoked ideas - 'credit maximizing' scientists, for example - with a familiar economic ring. Some commentators even identified it with the economics of scientific knowledge (ESK) literature (Davis 1997). But this line of CSS reasoning has been largely abandoned by its original proponents, perhaps because scholarship emphasizing invisible-hand outcomes shows that interested scientists need not entail bad outcomes in science (Hull 1988, Goldman and Shaked 1991, Kitcher 1993).

Since I am here taking the possibility of scientific success as a premise, I will not argue against the CSS conception of scientific knowledge in the large. Rather, I point out that the two CSS debunking strategies - one emphasizing interested scientists, the other emphasizing the toothlessness of empirical evidence - are at odds, so that the CSS theory of science is inconsistent. In particular, the CSS epistemic stance conflicts with its own interest-based view of scientific motivation, and it also undermines naturalized theory of science, CSS included.

The CSS view of empirical evidence is hard to square with its theory of scientific motivation. Even if scientists care only to promote their own noncognitive goals, they need to be empirical to do so. If they seek to promote their own interests, then they must attend to the relative efficacy of past interest-promoting strategies, an empirical task. But if scientists can never be influenced by empirical evidence, then they cannot examine history (or any other evidence) and are helpless to advance their own interests ${ }^{12}$ (Laudan 1990: 159-60). This paradoxical conclusion shows how extreme is the CSS position on evidence.

The CSS variant of science-studies naturalism is also at odds with, or at least made puzzling by its view of the role of empirical evidence in science. When naturalizing theorists of science argue for a scientific approach to 
science studies, they have in mind an empirical approach (Hausman 1992: 221). CSS advocates the use of sociological (and other) methods in science studies, which is unobjectionable by itself, but is clearly at odds with the CSS claim that scientific belief is never determined by empirical evidence. It is, at a minimum, a puzzling programme that offers lots of evidence for the proposition that evidence is immaterial (Laudan cited Hull 1988:4). Why should we treat seriously the scientific claims of a research programme that, by its own sweeping indictment, cannot be scientific? ${ }^{13}$ A naturalized approach to the theory of science - which proposes to import the techniques of empirical science - cannot be made coherent with a view of knowledge that denies a priori all prospect for empirically successful science.

Perhaps because it substitutes 'it's all social' for the Received View's 'it's all natural', CSS looks curiously traditional, at least in its all-or-nothing aspect. CSS presumes, as did the Received View, that the social character of science would necessarily undermine knowledge. And, in abandoning the normative project of theory of science, CSS essentially follows the Received-View practice of indifference to whether scientific practices are incentive compatible, i.e., whether they tend to promote or to undermine knowledge production. ${ }^{14}$

Just as the Received View took its 'science is natural' credo as license to focus on warrant wholly at the expense of acceptance, CSS takes its credo 'science is social' to focus on acceptance wholly at the expense of warrant. A more moderate perspective, the one argued for here, regards science as having a social character, but also sees scientific belief as informed by empirical evidence. It regards 'science as social' not as an argument-ending claim in epistemology, but as a mandate for inquiring into how the social character of science promotes or undermines knowledge, notably how social factors lead (or fail to lead) fallible, interested inquirers to accept what is empirically warranted (Haack 1998: 110).

These very different interpretations of what is meant by 'science is social' can be illustrated by the social practice of relying upon experts. Scientists routinely trust (without verification) the opinions of people they regard as scientific authorities. Though trust is not without clear risks, it can be perfectly rational - it amounts to an epistemic division of labour (Goldman 1995b: 746). Because independently assaying every claim that a scientist accepts in trying to produce knowledge is prohibitively expensive, the social practice of relying on expert authorities is an economizing practice necessary for the possibility of scientific progress. The CSS scholar, who identifies acceptance with empirical warrant, regards the practice of trusting authorities in wholly non-cognitive terms. Scientists defer to authority for reasons of social hierarchy, say, or to logroll, i.e., to gain reciprocal favours for flattering powerful people. Without denying that such factors are possibly in play, a moderate theory of science, which sees empirical warrant and acceptance as distinguishable, also inquires into whether authorities can be seen as signaling 
the reliability of the claim in question. The signal may well be faulty, of course, for the putative authority may be corrupt or wrong, thus the practice of trusting authorities will be epistemologically good depending on the extent to which authorities are indeed authoritative (Ibid.). Accurate or not, though, the expert's acceptance signals empirical warrant; it does not constitute empirical warrant. When Charles Sanders Peirce condemned as inferior scientific belief arising from authority, he had in mind thoughtless (or coerced) deference to political or religious authority, the kind, for example, that made Stalin-era Lysenkoism infamous (Peirce 1877). But the prospect that considered trust may be individually rational (and socially economizing), is precisely why one wants to inquire into, among other things, the efficacy of the social processes by which some scientists come to be regarded as authoritative.

\section{WHEREIN SUCCESSFUL SCIENCE: RELIABLE KNOWLEDGE}

Epistemology traditionally defines knowledge as justified true belief. ${ }^{15}$ To know something, you must have a belief, the belief must be true - you cannot know something that is not true - and the true belief must be justified. The 'justification' requirement ordinarily means that justified true beliefs are built atop secure foundations to knowledge - for example, atop beliefs that are self-evidently true - or are logically coherent with other beliefs already regarded as true. Both foundational and coherentist approaches to justification emphasize the ability to connect, vertically or horizontally, a given belief with other beliefs regarded as unimpeachable.

The trouble with the traditional conception of justification, noted by many, is that it sets the bar too high. Says David Hull:

[T] he content . . . of science can[not] be 'justified' in the sense that generations of epistemologists have attempted to justify them. The reason that epistemologists have not been able to justify knowledgeclaims in their sense of 'justify' is that no such justification exists. They want the impossible.

(1988: 12-13)

CSS scholars read the failure of science to achieve the impossible not as an indictment of the traditional conception of knowledge, but as entailing the impossibility of producing knowledge in general. Paradoxically, the CSS reading is true only if CSS scholars accept the traditional definition of knowledge. Kuhn puts it as follows:

[CSS theories of science] are taking the traditional view of scientific knowledge too much for granted. They seem, that is, to feel that traditional philosophy of science was correct in its understanding of what knowledge 
must be . . . . If science doesn't produce knowledge in that sense, they conclude, then it cannot be producing knowledge at all.

(Kuhn 1992: 9)

An alternative approach, used in this paper, is to adopt a more pragmatic and more modest conception of knowledge. I use reliabilism, an approach pioneered by Alvin Goldman (1986) and others, that qualifies a belief as epistemologically justified when it reliably indicates truth. One formulation says: a belief qualifies as knowledge if someone believes the proposition, it is true, and if it were not true, the cognizer would not believe it. For example, someone knows that the telephone is ringing, if he believes this, it is true, and, if the phone were not ringing, the cognizer would not believe that it was ringing, because he would not be having the same auditory experience. (The formulation and example are from Goldman 1995a). Reliability can refer to beliefs and to their mode of acquisition. Goldman has emphasized the reliability of the processes or practices by which beliefs are formed, where reliability consists of generating a fairly high ratio of true to false beliefs (truth ratio). Goldman uses the term 'veritism' to express the reliabilist's focus on the ability of beliefs and the modes of their acquisition to 'track' or 'hook up with' or 'indicate' truth (the adjective is 'veritistic') (Goldman 1995a, 1999: 87-94). Beliefs are states of knowledge, error or ignorance and have fundamental veritistic value (or disvalue), and practices have instrumental veritistic value insofar as they promote or impede veritistic beliefs (Goldman 1999: 87).

Economic considerations enter because states and practices with higher veritistic value will tend to be more economically valuable. There are clear incentives to adopt more veritistic beliefs and practices, given the costs (in time, effort and risk) to so doing. ${ }^{16}$ False beliefs or ignorance can lead me to lend money at one per cent while revolving credit at 18 per cent, or to prefer riskier investments with lower rates of return, or to regard a nominally higher (but, in real terms, lower) wage as increasing purchasing power, or to confuse legal and economic incidence of a sales tax. When a credible central bank adopts a tight-money policy, short term interest rates are likely to rise, and with them, the cost of financing goods bought on credit. This macroeconomic belief has positive if limited veritistic value, for the exact timing and magnitudes of changes in spending are hard to forecast. But one can be fairly sure of the direction of change, inexact knowledge that is economically valuable to informed decision makers.

More generally, seeing beliefs as at once fallible and valuable, has a leveling effect that shifts emphasis from the traditional (and CSS) epistemologist's allor-nothing appraisal, to consideration of the decision maker's practical judgment under uncertainty. The epistemologist who insists that beliefs are justified true belief or they are nothing is, in practice, a radical skeptic. In everyday life, such a stance would be paralyzing, a non-starter. It amounts to a kind of radical risk-aversion, an unwillingness to accept any cognitive risk, 
even when potential returns are large (Rescher 1989). A scientist who accepts the all-or-nothing criterion, effectively refuses to enter the cognitive enterprise (Rescher 1993: 86). The risk of cognitive error, along with other costs of inquiry, is the price of veritistically improved scientific beliefs and practices.

In practice, all but radical risk-averters are willing to risk error, time and money to gain greater veritistic value. But they face an information problem, because what is veritistically valuable in a belief or practice may not be known (Goldman 1999: 91). Veritistic value is not unknowable, but some veritistically valuable beliefs and practices may well be unknown. In science, the problem is especially acute, because the object is, in part, to produce novel claims - the benefits of research can be quite uncertain ex ante (Loasby 1989: 197). Even retrospectively, the value of scientific knowledge can be difficult to measure (Dasgupta and David 1994: 490). This is not an argument against rational consideration of beliefs and practices, it is a recognition that optimality may be difficult to realize or even undefined. Scientists, like the rest of us, take into account the costs and benefits of their choices as best they can, whether or not they can equate the marginal gain in veritistic value with the marginal cost of obtaining it.

\section{SCIENCE AS AN INVISIBLE-HAND PROCESS}

An invisible-hand process can be characterized by the following conditions: (1) individual actions lead to unintended consequences; (2) the aggregate effects of individual actions result in a spontaneous order ${ }^{17}$ that gives the appearance of design by a master planner, and (3) the order that results is deemed beneficial in ways that the individuals did not intend but nevertheless find desirable (Vaughan 1987). ${ }^{18}$ Adam Smith uses the term 'invisible hand' only twice in work published during his lifetime, most famously (and closest to the sense just defined) in the Wealth of Nations:

$[$ E]very individual ... neither intends to promote the public interest, nor knows how much he is promoting it .... [H]e intends only his own gain and it, and he is, in this as in many other cases, led by an invisible hand to promote an end which was no part of his intention. Nor is it always the worse for society that it was no part of it. By pursuing his own interest he frequently promotes that of society more effectually than when he really intends to promote it.

Strictly speaking, invisible-hand processes can also lead to collectively bad rather than good unintended consequences. Prisoners' Dilemma settings, such as certain common property resource problems (grazing land, riparian water, fisheries) provide an example. Common property resources are rivalrous in consumption and exclusion is costly, so self-regarding choices 
create external costs that unintendedly lead to inferior collective outcomes, i.e., to overuse or destruction of the resource. ${ }^{19}$

Invisible-hand arguments are uncommon and unpopular outside of economics, and science studies is no exception. It is not merely a predisposition among science-studies scholars to be skeptical of or even hostile to markets the leading example of invisible-hand processes - though it is true that science-studies scholars come from academic disciplines, sociology especially, founded (in the US) partly in opposition to a nascent neo-classical economics. The problem, I suggest, is more one of misconception.

Non-economists find it implausible that, absent the guiding visible hand of authority, self interested action can lead to good social outcomes. Or, more to the point, they tend to conflate invisible-hand explanations with a kind of laissez-faire. The conflation may arise from the term's close association with Adam Smith, and Smith's seminal role as the proponent of free trade against the mercantile view, the original debate over the proper scope of the state's role in the economy (Demsetz 1993: 159-60). But just as it is false to assume that the choice is dichotomous between central planning and anarchy, it is incorrect to cast the original invisible-hand theorists - David Hume, Adam Smith and others we might group into the Scottish Enlightenment - as proponents of vulgar laissez-faire. They were, in fact, clear that government had a crucial (if limited) role to play in underwriting invisible-hand outcomes. Smith conceived of his work as a 'science of the legislator,' that is, as advice to lawmakers on how to create an institutional structure that could best foster invisible-hand outcomes. In modern language, the invisible-hand theorists recognized that functioning markets rely upon laws that credibly establish and enforce the protection of persons, property, and contracts. Moreover, even 'free' markets undergirded by property and contact laws can fail to result in optimally good outcomes, what neoclassical economics came to call market failure. So, while invisible-hand explanations can be used to justify free markets, and are a rhetorical favorite of free marketeers, invisible-hand explanations should not be identified with laissez-faire. The case for free markets is one that sees state regulatory cures as worse than free market diseases. $^{20}$

Neoclassical economics has contributed to the misidentification of invisible-hand reasoning with laissez-faire by using the term 'invisible hand' as a casual label for a decentralized model of pricing that is ordinarily, if confusingly, called perfect competition. There is not much competition involved. In fact, there is no rivalry whatsoever: the competitive model refers to market and information conditions such that (maximizing) buyers and sellers behave as price takers. The only factors that affect choice are exogenously given tastes and technologies, and prices, which are determined impersonally in thick markets. ${ }^{21}$ All of these factors are beyond the control of any of the participants, and of any authority (Demsetz, ibid.), which may help explain the conflation of invisible-hand reasoning with laissez-faire. 
A subtler confusion results when science-studies scholars follow the neoclassical usage of 'invisible hand', to refer to the realization of Pareto-optimal equilibria. Wade Hands (1995), for example, takes Kitcher (1993) to task, on grounds that Kitcher's approach amounts to 'little more than Adam Smith's 'invisible hand' applied to the cognitive domain' (1995: 612). Hands uses 'invisible hand' in the neoclassical sense, that is, to refer 'the optimal allocation of our cognitive resources' (ibid.: 611). Adam Smith's invisible hand did not, of course, refer the optimality-cum-equilibrium emphasis of twentieth-century welfare economics.

Similarly, Hands (1997) criticizes Kitcher for employing an epistemic welfare economics, which among other things, involves risking the standard problems of neoclassical welfare economics - aggregation of individual demand functions into market demand, interdependent utilities, and so on. I think Hands's critique has merit: any naturalized approach to theory of science will import the weaknesses of its home discipline along with the strengths, and Kitcher's neoclassical economic approach is no exception. But Hands's argument is a critique of neoclassical welfare economics, or of its application in science studies, not of invisible-hand reasoning per se. ${ }^{22}$

A related example is Goldman and Cox's (1996) argument, in the context of free speech, against the claim that a free markets will always produce more true speech than will regulated markets. They point out that free markets may fail, and that even ideal markets do not intrinsically guarantee more truth. The reason is that ideal markets are those that most efficiently satisfy consumer preferences. And if consumers don't much value truth - preferring infotainment to hard news, say - then not much truth will be produced. Correct or not, Goldman and Cox interpret what they call 'marketplace theory' as (essentially) neo-classical perfect competition. ${ }^{23}$ Thus, though they invoke "Adam Smith's "invisible hand", their critique of the marketplace-of-ideas stance on truth production is not a critique of invisible-hand explanation.

Invisible-hand explanations do not entail optimality (in the sense of exhausting gains from trade) nor do they require decision making influenced only by price, nor do they imply that 'free' markets in speech necessarily produce relatively more true speech than more regulated markets.

A number of science studies scholars apply invisible-hand type reasoning to science (Hull 1988, Goldman and Shaked 1991, Kitcher 1993, Walstad 2001) even 'if, from these diverse efforts, a distinct movement has begun to take shape, its critics have been the first to notice' (Walstad 2001: 2). Only David Hull (1997) employs the term 'invisible hand', and all use different explanatory strategies. What unifies these various projects is the idea that science is successful not because real scientists are selfless truth seekers, but because science is socially organized in a epistemically beneficial way showing how (and under what circumstances) epistemically impure scientists can produce epistemically good outcomes. My own emphasis is on how 
scientific rules, ordinarily regarded as mere norms, induce fallible, interested scientists to produce reliable knowledge. ${ }^{24}$ In particular, do rules lead (or fail to lead) fallible inquirers to accept what is empirically warranted?

\section{SCIENTIFIC RULES AND EPISTEMICALLY VIRTUOUS INCENTIVES}

Let us proceed with rules in science by posing three fundamental questions concerning incentives in science: (1) why do scientists produce knowledge at all; (2) why do scientists openly publish their results; and (3) why do scientists tend to produce reliable knowledge?

Pioneering researchers in the economic of science were skeptical of the then commonplace Received-View notion that 'the search for knowledge is itself the highest social good and that any other benefits that society might obtain are just ... social gravy' (Nelson 1959: 299). This skepticism led them to ask why scientists produce knowledge at all (Arrow 1962). The 'old' economics of science begins with the idea that scientific knowledge is non-rivalrous in consumption. And, because the individual scientist has trouble appropriating the returns to a discovery (once made public), a market failure results - the under provision of a public good (or of a positive-externality good) owing to the divergence between individual and social returns (Dasgupta and David 1994: 490).

The remedy advocated was state intervention: the state produces the research; the state subsidizes research (claiming ownership of the output), or the state creates and protects intellectual property rights, which grants scientists temporary legal monopolies (generally patents), allowing producers to appropriate the returns. In emphasizing a regulatory solution to the knowledge-production market failure, the old economics of science literature did not attend to the question of how science - several centuries old historically managed to address the public-goods problem. In this sense, the early students in economics of science took the scientific rules, norms and conventions as given, to the extent they considered them at all (ibid.: 492).

Well before the advent of government science, science evolved a set of institutions to address its coordination problems. ${ }^{25}$ The institution that addresses the difficulty of excluding non-payers once knowledge is made public, is known as credit. Scientists who produce a valuable idea receive payment in the form of credit, generally via citation, and also via prizes, eponymy, and other forms of recognition. In science, reputation is the coin of the realm, and reputation can be seen as the stock of previous credit (and discredit). (See Latour and Woolgar 1986.)

If other scientists use your output (and acknowledge use), then you will be rewarded with credit. 'Just as the market rewards knowledge which enables someone to offer goods and services which customers wish to acquire, so the reputational system rewards those who produce new ideas which others can 
put to use: and if the goods or ideas are unwanted or defective, they will be ignored or criticized' (Loasby 1989: 39).

To argue that scientists seek credit does not require them to be indifferent to truth. Scientists likely want both. This may be so intrinsically: scientists want to be right, perhaps out of native curiosity, even as they also want credit - cashable in the form of higher wages, collegial esteem, promotions, etc. - for being right. Moreover, cognitive and non-cognitive goals need not be at odds - a more veritistic result can (and often does) lead to, for example, greater credit or greater profit. ${ }^{26}$

The evidence that scientists care about credit is compelling. Examining economists' salaries, Hamermesh finds that higher pay is robustly associated with greater citation (1989, cited in Colander 1989). Second, there is the relative paucity of anonymous publication. A credit-indifferent scientist might well publish anonymously (analogous to the anonymous charitable donor), but anonymously published results are the rare exception in the history of science. ${ }^{27}$ Third, consider the scientific institution of priority, the scientific convention of awarding first discoverers all the credit. The credit-indifferent scientist, who has only cognitive goals, should be indifferent to priority in discovery. ${ }^{28}$

Because credit ordinarily comes only with priority, the history of science is rife with priority disputes. Robert Merton documents that the battles over priority are fierce, recurring, and involve some of the greatest scientific names. Newton, Hooke, Liebniz, Huygens, Cavendish, Watt, Lavoisier, Faraday, LaPlace, several Bernoullis, Legendre, and Gauss are some of the worthies that Merton identifies as having been involved in priority disputes (1973 [1957]: 286-324). It's no different today. The most eminent scientists still squabble over, for example, who first isolated the human immunodeficiency virus thought to cause AIDS (Hull 1997). Were scientists indifferent to credit, which comes only with priority, we would not observe the recurrent priority disputes so characteristic of scientific history.

The way in which priority is determined helps answer our second question: why do scientists openly publish their results? In academic science, (1) credit is, as noted, generally awarded entirely to first discoverers (priority), and (2) the first to publish is deemed the first discoverer. It is unusual to get credit for results not published, or for results already published by others. ${ }^{29}$ To get credit you must be first to publish. ${ }^{30}$ The tradeoff for the scientist who wants credit is clear: waiting too long to publish risks losing priority and therefore credit, while rushing into print risks errors which, if they ramify, will lead to discredit (Hull 1988: 352). More pre-publication work increases reliability and thus expected credit, but consumes time that reduces expected credit.

Awarding credit based on priority, and awarding priority based on publication are rules that promote the virtues of more rapid scientific innovation and broader dissemination of knowledge. Merton referred to the norm of open publication (and the idea that scientific knowledge is 
common property) as an ethic of 'communism' (1973 [1942]: 273-5). But interested scientists can have incentives to keep their results secret, or to delay publication, so the rules qua norms are not, by themselves, incentive compatible. The incentive to publish is created by the rule that assigns credit to the first to publish.

What if profit as well as credit is at stake? The incentive to publish first can be overwhelmed when the value of expected profit, which requires secrecy, exceeds the value of expected credit. Secrecy characterizes industrial science, where profitable ideas are made public generally only with patent protection, so that the owner of the intellectual property can appropriate returns via temporary legal monopoly. Dasgupta and David (1987) distinguish science from technology on this very basis - science is, they argue, concerned with adding to the stock of scientific knowledge, and thus has the practice of open publication; technology, in contrast, is concerned with maximizing rents from a given stock of knowledge, and thus has a practice of secrecy. ${ }^{31}$ If profits increase at a faster rate than returns to academic reputation, then one would expect more defections from the academic model of open publication to the commercial model of secrecy, or an increased blurring of the line between academic and commercial research. ${ }^{32}$

Innovation and dissemination of ideas are not the only rationales for openness, so too is the policing function so characteristic of science - the certification of ideas as reliable. This takes us to our third query, why scientists produce reliable knowledge. There are two important scientific institutions here: peer review and replication.

Like all agents, individual scientists accept much on faith. Were scientists obliged to independently assay every bit of knowledge used in their research, science would stop. Reliability is nonetheless vital, so science has evolved a social system of trust, which is built upon a process of verification via peer review and replication. Scientists have some assurance that their knowledge inputs are reliable, when independent peer reviewers have directly assayed the ideas in question, or when subsequent 'users', if any, have indirectly done so.

Publication is generally necessary but not sufficient for obtaining credit. Credit accrues only when others use ideas, and they prove reliable. Ideas that prove unreliable bring discredit, and fall into disuse. In the empirical sciences, then, there are strong incentives to produce reliable knowledge. Research output is 'quality checked' not only by peer reviewers, but also by subsequent users.

I do not wish to suggest that peer review and replication are without problems. Replication is not a simple matter practically or philosophically (Collins 1985). In some fields, economics included (Mayer 1993b), direct positive replications (in the sense of reproducing a published result) are rarely publishable, so the returns to direct replication are lower than the returns to original research (Feigenbaum and Levy 1993). ${ }^{33}$ Some review processes are more demanding than others; the refereeing process is itself vulnerable to 
corruption. ${ }^{34}$ Moreover, it is probably the fate of most published papers never to be cited, much less to be checked. Holub et al. (1991) find about half of peer-reviewed papers in economic growth theory are never cited, and that 85 percent are cited five or fewer times. ${ }^{35}$

For papers that survive publication, replication is pervasive in the empirical sciences. Those who use other scientists' results as an input very much want those results to be reliable. Scientists are unlikely to sabotage their own research by choosing inputs known to be faulty. As such, a kind of indirect replication is in force, because serious errors will ultimately manifest themselves, with adverse reputational consequences for the scientists who are the source of the error (especially if due to fraud or carelessness).

Not all 'published' papers are peer reviewed. Working papers and other papers not yet peer reviewed are increasingly used and cited by scientists. Some repositories, such as the Social Science Research Network (http://www.ssrn.com), gather and index working papers. Others, such as the Los Alamos Physics Archive (http://xxx.lanl.gov/) also allow for open peer commentary - any reader can comment - as against the traditional process of refereeing by editorially-designated experts. Some journals augment peer review with open peer commentary. (On the virtues of open peer commentary versus peer review, see Harnad 2000.)

Though all scientific claims are corrigible, survival under the scrutiny of use is a tentative signal of reliability, and allows potential users to rely on the judgment of others. Direct replication, in contrast, where reliability is independently undertaken by the user, is costly in time and expense. Rivalry in science provides some incentive for scientists to undertake direct replication. It is unrealistic to expect scientists to rigorously attempt to refute their own hypotheses. But, as Hull points out, their rivals will be happy to do so (1988: 4). Competition helps promote replication, because competitors have an incentive to refute (or at least challenge) results they find inimical to their own work.

There is, for example, a well-known recent literature in labour economics which finds that recent minimum-wage increases do not result in adverse employment consequences for low-skilled workers (Card and Krueger 1995). Those who find this result congenial, such as political proponents of minimum-wage increases, are unlikely to scrutinize Card and Krueger's methods too closely. But those who believe that a minimum wage does have adverse employment consequences, and have built scientific reputations on this view, are likely to examine Card and Krueger's controversial findings rather sceptically, and have, in fact, done so. ${ }^{36}$ When the stakes are high enough, the ordinary disincentives to direct replications can be overcome.

In economics, where reliability is harder to come by than in the natural sciences, publication incentives with respect to positive replication can change over time. Goldfarb (1995) finds, in several empirical literatures, that the returns to positive replications (not checking per se, but 'confirming' results) 
are initially higher than negative replications (disconfirming results), but that, after a period of normal science, disconfirming results become relatively more attractive, that is, likelier to be published. (For more on replication in economics, see Backhouse 1997: 135-57.)

Because it helps promote replication, rivalry in science works to help eliminate error in a kind of self-correcting fashion. Errors get exposed not because scientists disinterestedly refute their own pet theories, but because their interested rivals have partisan incentives to do so. Moreover, interested rivals are generally the most qualified reviewers. Those with the greatest incentive to criticize are also those with the greatest expertise. Competition for credit induces scientists to rigorously assay their rivals' research, and is what Popper referred to when he said: 'should individual scientists ever become 'objective and rational' in the sense of 'impartial and detached', then we should indeed find the revolutionary aspect of science barred by an impenetrable obstacle' (1975: 93, cited in Hull 1988: 359).

But competition among scientific rivals is tempered by a mutual dependency that arises from specialization in the division of cognitive labour, and from the way in which credit is assigned. Scientists produce and consume knowledge, or, perhaps more accurately, they use the output of other scientists as a capital-good-type input in their own production (Ghiselin 1989). As such, scientists partly depend on suppliers who are also their rivals in the output market. Scientists are likely to benefit cognitively from using their rivals' results. Rivals are, after all, working on similar problems and, given specialization, are the likeliest source for improving the reliability of one's own work.

Scientists need their competitors's work as an input, and they also need their rivals' support. A scientist wants other scientists to make use of his output. This is not merely professional pride, but the fact that credit obtains only when fellow producers award it. Scientists need their rivals: they need their rivals' work to meet cognitive goals, and need their rivals' attention to obtain the credit that comes only from use. Thus is competition in science tempered by a kind of mutual dependency (on this, see Hull 1998, 1997).

Mutual dependency of rivals goes to another incentive question: why scientists generally give credit where credit is due. Why, for example, do scientists generally practice honest citation, when it is costless to plagiarize (in whole or in part) and thereby receive credit for ideas one didn't actually produce? One might get caught, of course, with the attendant reputational disaster likely to follow. But plagiarism, unlike unreliable work where errors eventually manifest in future research, is not subject to indirect replication. The determined plagiarist can go a surprisingly long time before detection (Kohn 1986).

Mutual interest among scientists, however, creates an incentive to cite others, in order to enlist their support, which is necessary for obtaining credit. We need our fellow scientists, in part for their output, and in part for their 
support, without which credit for our own output cannot be had. Honest citation is not only a Mertonian norm - respect for others' intellectual property - nor is it motivated solely by fear of detection. Mutual dependence also makes it in the scientist's interest to cite properly.

\section{CONCLUSION}

The forgoing assumes that learned inquirers and everyday agents value and can obtain reliable knowledge at reasonable cost, which in turn presupposes an enterprise with the incentive and the ability to inquire empirically. In some enterprises, such as those that consider ethics or aesthetics or spirituality, reliable knowledge may be impossible. In other places, reliable knowledge may be too costly, or may not be highly valued. In these domains, where the way the world is cannot or does not meaningfully constrain what is believed to be, reliable knowledge is beside the point, and the scientific rules I have argued help promote reliable knowledge cannot do so.

When science does succeed in proceeding reliable knowledge, it succeeds in part because its institutions are robust - credit, priority, open publication, peer review, and replication. The reputational system induces scientists to openly and rapidly produce ideas by rewarding them with credit. Peer review and (direct and indirect) replication provide additional incentives to produce ideas that are reliable. When scientists change their mind, it is not merely a matter of personal virtue. In the long run, scientists have powerful incentives to use reliable ideas and to eschew unreliable ones, even when there is an unhappy difference what they want to be true and what they take to be true (Galison 1987).

I do not claim, and know no one who does, that science always produces reliable knowledge. Scientific rules, norms and conventions are imperfect; they are not all self-enforcing, and they likely reflect path-dependant inefficiencies. But this is true of markets, too. Like markets, science is successful because it has robust institutions, and thus fails only some of the time.

\section{ACKNOWLEDGMENTS}

I gratefully acknowledge, without implicating them in the much revised arguments presented here, the constructive criticisms of Wade Hands, Jim Wible, John Davis, Alan Walstad, Bob Goldfarb, numerous seminar participants, and the referees.

Thomas C. Leonard

Princeton University tleonard@princeton.edu 


\section{NOTES}

1 The term 'critical science studies' was suggested by a referee.

2 Some students of science take seriously the idea that scientific success is pure happenstance. Mary Hesse, for example, says; 'science might, after all, be a miracle' (1980: 154).

3 Economics entered the science-studies derby late, and the earliest retailers of economic ideas were typically philosophers (Hull 1988, Rescher 1989, Kitcher 1993), though there are exceptions, such as Tullock 1966. Science studies incumbents tend to be hostile or indifferent to economic thought, at least its mainstream variant. (See Mirowski and Sent (2002) for a stimulating compendium of critiques). Even in economic methodology, economically informed approaches to methodology are comparatively uncommon. Some exceptions, again, are Wible (1998), Colander (1989), Feigenbaum and Levy (1993), Mayer (1993a). For more on economics in science studies, see Hands 2001, chapter 8 .

4 Theories are regarded as empirically equivalent when they have identical empirical consequences (Laudan and Leplin 1991: 451). Since it is easy to generate theoretical 'alternatives' by trivially changing a current theory (Cross 1998), there are, logically at least, an indefinite number of empirically equivalent theories. An indefinite number of rival theories entailing the same empirical consequences does seem to imply underdetermination, since any actual evidence would support (or disconfirm) all rivals equally. (This paragraph and footnote is taken, somewhat altered, from Goldfarb et al. 2001.)

5 'Strategies' is plural by design, a recognition that empirical methods in science are heterogeneous. Ian Hacking (1983: 152) says: 'There is not just one way to build a house or even to grow tomatoes. We should not expect something as motley as the growth of knowledge to be strapped to one methodology.'

6 The term 'naturalism', as used in the epistemological context, is due to Quine (1969).

7 Thus, notwithstanding his emphasis on scientific motivation, Popper remains close to the traditional philosophers of science with respect to the nature and status of meta-scientific claims.

8 Charles Sanders Peirce proposed it nearly a century earlier, saying, "philosophy ought to imitate the successful sciences in its methods...' (cited in Wimsatt 1981: 124).

9 Cole (1992), from which the Merton citations are obtained, reports that Merton added this quote as a note in the 1957 reprint of Merton's famous 1942 paper on scientific norms. Intriguingly, when the paper was added to the 1973 collection of Merton's papers, Merton altered the last sentence to read: 'Sooner or later, competing claims to validity are settled by universalistic criteria' (Cole 1992: 4).

10 Quine's (1953) read empirical equivalence of rival theories as entailing epistemological equality, thereby reducing theory choice to wholly non-evidential(his term is 'pragmatic') considerations. But it is far from clear that actual theoretical rivals are empirically equivalent. It may be that trivial changes don't create genuinely distinct theories, which is why it is difficult to find real-world examples of genuinely distinct empirical equivalents, and the few we have offer little warrant for the sweeping claim that there are likely empirical equivalents to most theories. Quine himself later suggested that incompatible empirically equivalent theories might not be genuine rivals, but, instead, verbal variants of the same theory (Quine 1981:23-30, cited in Haack 1998: 101, n. 6). Laudan and Leplin argue that underdetermination does not follow from empirical equivalence unless empirical 
consequences are improperly identified with evidential support. When evidential support for a theory is not limited to instances that are the direct consequences of the theory, epistemologically warranted choices among rivals are still possible. One way is indirect evidential support. Consider two empirically equivalent hypotheses $\left(H_{1}\right.$ and $\left.H_{2}\right)$, where only $H_{1}$ is derivable from a more general theory $\mathrm{T}$, which also implies another hypothesis $\mathrm{H}$. Empirical consequence $(\mathrm{E})$ of $\mathrm{H}$ is observed repeatedly (many instances), which supports $\mathrm{H}$ and thereby $\mathrm{T}$, also lending indirect evidential support for $H_{1}$ but not $H_{2}$. E is not a consequence of $H_{1}$ or $H_{2}$ but nonetheless offers an evidential basis for preferring $H_{1}$, ceteris paribus (Laudan and Leplin 1991: 464). (This footnote is taken, somewhat altered, from Goldfarb et al. 2001.)

11 CSS thus turns the Received View's conception of theory justification on its head. The Received View says that scientists accept a claim because there is empirical warrant for it. Warrant (eventually) causes acceptance. CSS inverts the traditional causality: it says acceptance is what determines warrant. In some CSS versions, warrant for a claim is said to consist of acceptance. Say David Bloor:

Instead of defining it as true belief, knowledge for the sociologist is whatever men take to be knowledge.... Of course knowledge must be distinguished from mere belief. This can be done by reserving the term 'knowledge' for what is collectively endorsed, leaving the individual and idiosyncratic to count as mere belief

(1976: 2-3, cited in Mäki 1992: 62).

12 Philip Kitcher argues: 'To see how bizarre this [CSS view of how empirical evidence is immaterial] is, we should note that the point also seems to show that society can have no bearing on what scientists accept' (1998: 40, emphasis added).

13 Latour and Woolgar (1986), for example, use ethnographic research methods in studying what scientists do in the lab. If their observationaldata were not intended as evidence for the validity of their claims about laboratory life, what were they for?

14 It is a measure of the polarization in contemporary science studies, that one feels obliged to note what should go without saying: there is nothing in a sociological or anthropological or historical approach to science that per se requires a radically skeptical attitude towards scientific knowledge. And, though again it should go without saying, many science studies scholars do not endorse the CSS view.

15 Philosophers have located counterfactual examples, justified true beliefs that shouldn't be regarded as knowledge (Gettier 1963).

16 Veritistic and economic value should not be confused. Some epistemological positions, however, such as the pragmatism of William James, propose that truth consists in something we find it valuable to believe.

17 The term 'spontaneous order' is due to Friedrich Hayek, who meant it to be distinguished from a consciously planned or designed order. Hayek often cited Adam Ferguson in this respect, who characterized spontaneously evolved orders as those that 'are of human action, but not of human design.' (Hayek 1973: 20).

18 The process is called invisible because it is ordinarily thought to work without the knowledge of the participants. Whether this is true or a requirement of the definition is debated. See Ullmann-Margalit 1978.

19 Some writers reserve the term 'the invisible backhand' for such outcomes (Brennan and Petit 1993). Following convention, I use 'invisible hand' to refer to beneficial outcomes only - the successful alignment of individual and collective interests. 
20 The invisible-hand theorists $d o$ represent a profound change in political philosophy, a shift from virtue to justice. No longer is government's purpose to morally instruct - to attempt to create a virtuous citizenry - it is, rather, to underwrite and enforce rules that are the essential preconditions to successful commercial society. Nonetheless, the invisible hand theorists were themselves, in some sense, motivated by virtue. They believed that, in a commercial society, their more modern conception of government would better serve the common good. These points are due to Jerry Muller (1993).

21 With no missing markets, this is sufficient to ensure Pareto optimality. Collusion is desirable to agents but precluded by the (known) fact that no sustainable coalition of sellers (or buyers) can control a large enough share of the market to affect price.

22 This may help explain why Kitcher's critics in economics insist on the label 'invisible-hand' (e.g., Mirowski 1996), when Kitcher himself, in a long and closely reasoned book, never once uses the term.

23 My own view is that Goldman and Cox (1996) too quickly identify the casual 'marketplace of ideas' metaphor with neoclassical perfect competition, and find that the latter will not produce more truth as claimed by proponents of former. In a later, revised version of Goldman and Cox (1996), Goldman more carefully distinguishes the neoclassical economic sense of competitive markets - price rivalry to serve consumers - from the marketplace-of-ideas sense, which refers more to open, vigorous debate of diverse opinions (1999: 189-217).

24 I use 'reliable knowledge' as a rough synonym for veritistically valuable beliefs, though the attributes that make a belief or practice veritistically valuable go beyond reliability. Wade Hands (2001: 146-148) notes that Goldman (1987) invokes other standards: power (problem-solving ability), fecundity, speed (how quickly beliefs are processed) and efficiency, and observes that scientists may need to trade off these virtues when they are opposed.

25 It is with reluctance that I use the term 'institution' as a rubric for rules, norms and conventions (and their enforcement) in science. The term 'institution' means different things to Old Institutionalists and New Institutionalists, to say nothing of others, and it is notoriously resistant to precise definition. John R. Commons noted the difficulty of a decent definition in Commons 1934. Geoff Hodgson's (1998) attempt to characterize the 'hard core propositions' of old Institutionalism does not hazard an attempt at definition until 13 pages into the article, providing an illustration of how the term remains elusive, even when in skillful and sympathetic hands.

26 Of course, if the returns to fraud, for example, are deemed relatively higher, then profit seeking need not promote truth seeking (see Wible 1998: 43-60).

27 The mathematicians who wrote under the pseudonym Nicholas Bourbaki are an interesting exception, as noted in Hull 1997.

28 Even the pure truth-seeker, however, can see instrumental value in credit. If credit leads to more funding and to greater opportunities to produce knowledge, then credit can be an instrumental if not an intrinsic goal for the pure truth seeker.

29 By 'published,' I mean 'made public,' or 'openly disclosed'. Working papers or webbed papers are, in this sense, published. Publication in refereed outlets entails peer review, discussed below. One can find historical examples of credit awarded to scientists who were second in a race, or who never bothered to formally publish their results, but they are exceptional. Multiple independent discoveries, such as the invention of the calculus by both Newton and Liebniz, are a different matter (see Merton 1973: 343-70).

30 Though see Steve Stigler's (1980) Law of Eponymy: 'No scientific discovery is 
named after its original discover.' If Stigler's Law self-applies, then giving Stigler credit may be giving credit where credit is not due.

31 There are other incentive effects which we do not take up here. For example, priority's winner-take-all structure creates incentives for rapid innovation, but it also can result in wasteful ex post gamesmanship (Merton 1973: 317), and in socially inefficient expenditures analogous to the patent-race problem (Daspgupta and David 1994).

32 The academic norm of openness and the commercial norm of secrecy conflict in an interesting way when academic research threatens intellectual property protection. Academic computer scientists, for example, who want to publish papers that show how to circumvent the copy-protection codes in software and recorded music often face litigation by industry groups, often even when firms hire them to find such weaknesses.

33 Replication is rare in economics, and econometric results that are revisited are notoriously hard to reproduce. An organized attempt at replication, funded by the US National Science Foundation, reviewed empirical papers submitted to the Journal of Money, Credit and Banking from 1980 to 1982 (DeWald et al. 1986). Of 154 original authors notified, only in 90 cases were authors willing and able to supply data and programs. The replicators reviewed 54 of these data sets, and found that only eight were sufficiently free of problems to permit an attempt at replication. And, only in two of the remaining eight papers were the results actually reproduced in full. The review team was thus able to fully reproduce econometric results only 3.7 per cent $(2 / 54)$ of the time. Replicators were attempting replication only in the narrow sense of reproducing results, using original data sets and statistical procedures.

34 Arthur Diamond (1986) estimates the present value of an additional publication (in 1994 dollars) to a 35-year-old academic mathematician as about $\$ 6,750$ (cited in Stephan 1996: 1203). The editor of a journal which publishes 50 articles a year could develop a remunerative sideline, particularly where the marginaldifferences among published and unpublished papers are small. Less egregious and more common forms of corruption are nepotism and logrolling.

35 In a sample of the 1,187 papers published in the 1963 volume of Physical Review, one half received zero or one citations in the subsequent three years, and only 15 per cent received six or more citations (Cole 1992: 16).

36 See, for example, Neumark and Wascher (1995), and Hamermesh (1995). For more on the controversy, see Leonard (2000).

\section{REFERENCES}

Archibald, G. (1967) 'Refutation or comparison?', British Journalfor the Philosophyof Science 17: 279-96.

Aronowitz, Stanley (1988) Science as Power: Discourse and Ideology in Modern Society. Minneapolis: University of Minnesota Press.

Arrow, Kenneth (1962) 'Economic welfare and the allocation of resources for unvention', in R.R. Nelson (ed.), The Rate and Direction of Inventive Activity: Economic and Social Factors, Princeton, NJ: Princeton University Press: pp. 609-25.

Backhouse, Roger (1997) Truth and Progress in Economic Knowledge, Cheltenham, UK: Edward Elgar.

Brennan, Geoffrey and Pettit, Philip (1993) 'Hands invisible and intangible', Synthese 94: 191-225.

Callebaut, Werner (1993) Taking the Naturalist Turn or How Real Philosophy of Science is Done, Chicago: University of Chicago Press. 
Card, David and Krueger, Alan (1995) Myth and Measurement: The New Economics of The Minimum Wage, Princeton, NJ: Princeton University Press.

Colander, David (1989) 'Research on the economics profession', Journal of Economic Perspectives 3(4): 137-48.

Cole, Stephen (1992) Making Science: Between Nature and Society, Cambridge, MA: Harvard University Press.

Collins, Harry (1981) 'Stages in the empirical programme of relativism', Social Studies of Science 11: 3-10.

Collins, Harry (1985) Changing Order: Replication and Induction in Scientific Practices, London: Sage Publications.

Collins, Harry and Yearly, Steven (1992) 'Journey into space,' in A. Pickering (ed.), Science as Practice and Culture, Chicago: University of Chicago Press: 369-89.

Commons, John R. (1934) Institutional Economics: Its Place in Political Economym New York: Macmillan.

Cross, Rod (1998). 'The Duhem-Quine hypothesis', in John B. Davis, D. Wade Hands and Ischial Mäki (eds) The Handbook of Economic Methodology. Cheltenham, UK: Edward Elgar: pp. 107-10.

Daspgupta,Partha and David, Paul (1987) 'Information disclosure and the economics of science and technology', In George Feiwel (ed.) Arrow and the Ascent of Modern Economic Theory, London: Macmillan Press: pp. 519-42.

Daspgupta, Partha and David, Paul (1994) 'Towards a new economics of science', Research Policy 23: 487-521.

Demsetz, Harold (1993) 'The theory of the firm revisted', in Oliver Williamson and Sidney Winter (eds) The Nature of The Firm, New York: Oxford University Press: pp. 159-78.

Davis, John B. (1997) 'The fox and the henhouses: the economics of scientific knowledge', History of Political Economy 29(4): 741-46.

DeWald, W.G., Thursby, J.G. and Anderson, R.G. (1986) 'Replication in empirical economics: the Journal of Money, Credit and Banking project', American Economic Review 76(4): 587-603.

Diamond, Arthur (1986) 'How much is a citation worth?', Journal of Human Resources 21(2): 200-15.

Feigenbaum, Susan and Levy, David (1993) 'The market for (Ir)reproducible econometrics', Social Epistemology 7(3): 215-32.

Feyerabend, Paul (1975) Against Method: Outline of an Anarchistic Theory of Knowledge, London: Verso.

Galison, Peter (1987) How Experiments End, Chicago: University of Chicago Press.

Gettier, Edmund (1963) 'Is justified true belief knowledge?' Analysis 23: 121-23.

Ghiselin, Michael (1989) Intellectual Compromise, New York: Paragon House.

Goldfarb, Robert (1995) 'The economist-as-audience needs a methodology of plausible inference', Journal of Economic Methodology 2(2): 201-22.

Goldfarb, Robert, Leonard, Thomas C. and Suranovic, Steven (2001) 'Are rival theories of smoking underdetermined?', Journal of Economic Methodology 8(2): 229-51.

Goldman, Alvin (1986) Epistemology and Cognition, Cambridge, MA: Harvard University Press.

Goldman, Alvin (1987) 'Foundations of social epistemics', Synthese 73: 109-44.

Goldman, Alvin (1995a) 'Reliablism' in Robert Audi (ed.) The Cambridge Dictionary of Philosophy, Cambridge University Press: 693.

Goldman, Alvin (1995b) 'Social epistemology' in Robert Audi (ed.) The Cambridge Dictionary of Philosophy, Cambridge University Press: 746. 
Goldman, Alvin (1999) Knowledge in a Social World, Cambridge: Cambridge University Press.

Goldman, Alvin and Cox, James (1996) 'Speech, truth and the free market for ideas', Legal Theory 2: 1-32.

Goldman, Alvin and Shaked, Moishe (1991) 'An economic model of scientific activity and truth acquisition', Philosophical Studies 63: 31-55.

Haack, Susan (1998) Manifesto of a Passionate Moderate, Chicago: University of Chicago Press.

Hacking, Ian (1983) Representing and Intervening, Cambridge: Cambridge University Press.

Hamermesh, Daniel (1995) 'Comment' for Review Symposium, on Myth and Measurement: The New Economics of the Minimum Wage, Industrial and Labor Relations Review 48(4): 835-38.

Hands, D. Wade (1995) 'Social Epistemology meets the Invisible Hand: Kitcher on the Advancement of Science', Dialogue 34: 605-21.

Hands, D. Wade (1997) 'Caveat emptor: economics and contemporary philosophy of science', Philosophy of Science (Proceedings) 64: S107-16.

Hands, D. Wade (2001) Reflection Without Rules: Economic Methodology and Contemporary Science Theory, Cambridge: Cambridge University Press.

Harnad, Steven. (2000) 'The invisible hand of peer review', Exploit Interactive 5 (April).

Hausman, Daniel (1992) Essays on Philosophy and Economic Methodology, Cambridge: Cambridge University Press.

Hayek, Friedrich (1973) Law, Legislation and Liberty, Volume One: Rules and Order, Chicago: University of Chicago Press.

Hesse, Mary (1980) Revolutions and Reconstructions in the Philosophy of Science, Bloomington, IN: Indiana University Press.

Hodgson, Geoff (1998) 'The approach of institutional economics', Journal of Economic Literature 36: 166-92.

Hollis, Martin (1994) The Philosophy of Social Science, Cambridge: Cambridge University Press.

Holub, Hans Werner, Tappeiner, Gottfried and Eberharter, Veronika (1991) 'The iron law of important articles', Southern Economic Journal (58): 317-28.

Hull, David (1988) Science as a Process, Chicago: University of Chicago Press.

Hull, David (1997) 'What's wrong with invisible-hand explanations?', Philosophy of Science (Proceedings) 64(4): S117-26.

Kitcher, Philip (1993) The Advancement of Science: Science Without Legend, Objectivity Without Illusions, Oxford: Oxford University Press.

Kitcher, Philip (1998). 'A plea for science studies', in Noretta Koertge (ed.) A House Built on Sand, New York: Oxford University Press: pp. 32-56.

Kohn, Alexander (1986) False Prophets, Oxford: Basil Blackwell.

Kuhn, Thomas (1992) The Trouble with the Historical Philosophy of Science (Robert and Maurine Rothschild Distinguished Lecture), Cambridge: Department of the History of Science, Harvard University.

Kuhn, Thomas (1996) [1962] The Structure of Scientific Revolutions 3rd edition, Chicago: University of Chicago Press.

Lakatos, Imre (1978) The Methodology of Scientific Research Programs, Volume I. John Worrall and Gregory Currie (eds), Cambridge: Cambridge University Press.

Latour, Bruno (1987) Science in Action, Cambridge, MA: Harvard University Press

Latour, Bruno and Steve Woolgar (1986) [1979] Laboratory Life: The Construction of Scientific Facts 2nd edition, Princeton, NJ: Princeton University Press. 
Laudan, Larry (1984) Science and Values: The Aims of Science and Their Role in Scientific Debate. Berkeley: University of California Press.

Laudan, Larry (1990) Science and Relativism: Some Key Controversies in the Philosophy of Science, Chicago: University of Chicago Press.

Laudan, Larry and Leplin, Jarrett (1991) 'Empirical Equivalence and Underdetermination', The Journal of Philosophy 88(9): 449-72.

Leonard, Thomas (2000) 'The very idea of applied economics: the modern minimumwage controversy and its antecedents', History of Political Economy, Supplement to Volume 32, Roger Backhouse and Jeff Biddle (eds) Durham, NC: Duke University Press: $117-44$.

Loasby, Brian (1989) The Mind and Method of the Economist, Brookfield, VT: Edward Elgar.

Mäki, Uskali (1992) 'Social conditioning of economics', in Neil de Marchi (ed.) Post-Popperian Methodology of Economics: Recovering Practice, Boston: Kluwer: 65-104.

Mayer, Thomas (1993a) Truth versus Precision in Economics, Brookfield, VT: Edward Elgar.

Mayer, Thomas (1993b) 'Commentary on The Scientific Status of Econometrics', Social Epistemology 7(3): 269-73.

Merton, Robert (1973) The Sociology of Science, Norman Storer (ed.), Chicago: University of Chicago Press.

Mirowski, Philip (1996) 'The economic consequences of Philip Kitcher', Social Epistemology 10: 153-170.

Mirowski, Philip and Sent, Esther-Mirjam (eds) (2002) Science Bought and Sold: The New Economics of Science, Chicago: University of Chicago Press.

Muller, Jerry (1993) Adam Smith in His Time and in Ours: Designing the Decent Society, New York: Free Press.

Nelson, Richard (1959) 'The simple economics of basic scientific research', Journal of Political Economy 67(3): 297-306.

Neumark, David and Wascher, William (1995) 'The effect of New Jersey's minimum wage increase on fast-food employment: a reevaluation using payroll records', NBER Working Paper No. 5224, Cambridge, MA: NBER.

Peirce, Charles Sanders (1877) 'The fixation of belief' Population Science Monthly 12: $1-15$.

Popper, Karl (1959) The Logic of Scientific Discovery, London: Hutchison.

Popper, Karl (1972) Objective Knowledge: An Evolutionary Approach, Oxford: Clarendon Press.

Popper, Karl (1975) 'The rationality of scientific revolutions', in Rom Harre (ed.) Problems of Scientific Revolution, Oxford: Clarendon Press: 72-101.

Quine, Willard (1953) 'Two dogmas of empiricism', in From A Logical Point of View, Cambridge, MA: Harvard University Press: pp. 20-46.

Quine, Willard (1969) 'Epistemology naturalized', in Ontological Relativity and Other Essays in the Philosophy of Science, New York: Columbia University Press: 69-90.

Rescher, Nicholas (1989) Cognitive Economy: The Economic Dimension of The Theory of Knowledge, Pittsburgh: University of Pittsburgh Press.

Rescher, Nicholas (1993) Pluralism: Against the Demand for Consensus, Oxford: Clarendon Press.

Smith, Adam (1937) [1776] An Inquiry into The Nature and Causes of The Wealth of Nations, New York: Modern Library

Stephan, Paula (1996) 'The economics of science', Journal of Economic Literature 34(3): 1199-1235. 
Stigler, Steve M. (1980) 'Stigler's law of eponymy', Transactions of the New York Academy of Sciences, 39:147-57.

Suppe, Fred (ed.) (1977) The Structure of Scientific Theories 2nd ed., Urbana: University of Illinois Press.

Tullock, Gordon(1966) The Organization of Inquiry, Durham: Duke University Press.

Vaughan, Karen (1987) 'Invisible hand', in John Eatwell, Murray Milgate and Peter Newman (eds) The New Palgrave: The Invisible Hand, New York: W.W. Norton: pp. 168-72.

Ullmann-Margalit, Edna (1978) 'Invisible Hand Explanations', Synthese 39(2): 263-91.

Walstad, Alan (2001) 'On science as a free market', Manuscript.

Wible, James (1998) The Economics of Science: Methodology and Epistemology as if Economics Really Mattered, London: Routledge.

Wimsatt, William (1981) 'Robustness, reliability and overdetermination', in Marilyn Brewer and Barry Collins (eds), Scientific Inquiry and the Social Sciences, San Francisco: Jossey-Bass: pp. 124-63. 